\title{
COMMENTS
}

\section{DEFENSE WITNESS IMMUNITY AND THE RIGHT TO A FAIR TRIAL}

The notion that a defendant has a right to defense witness immunity was born in a footnote fourteen years ago. ${ }^{1}$ Since then, commentators have strongly supported the right, ${ }^{2}$ but most courts

1 See Earl v. United States, 361 F.2d 531, 534 n.I (D.C. Cir. 1966), cert. denied, 388 U.S. 921 (1967). In Earl, the District of Columbia Circuit held that the government's refusal to grant statutory immunity to a defense witness who had invoked his fifth amendment privilege against self-incrimination did not deprive the defendant of due process. Nonetheless, Chief Justice Warren Burger, then a circuit judge, remarked in a footnote:

We might have quite different, and more difficult, problems had the Government in this case secured testimony from one eyewitness by granting him immunity while declining to seek an immunity grant for Scott to free him from possible incrimination to testify for Earl. That situation would vividly dramatize an argument on behalf of Earl that the statute as applied denied him due process. Arguments could be advanced that in the particular case the Government could not use the immunity statute for its advantage unless Congress made the same mechanism available to the accused. . . .

Id. (emphasis in original). The question was posed only hypothetically because the government had not granted immunity to any of its witnesses.

The government's power to compel testimony in exchange for immunity is provided by 18 U.S.C. $\$ \S 6001-6005$ (1976). Under this statute, the government may grant "use immunity," meaning that no testimony compelled under the statute, or "information directly or indirectly derived from such testimony... may be used against the witness in any criminal case, except a prosecution for perjury, giving a false statement, or otherwise failing to comply with the order." Id. $\$ 6002$.

Use immunity is more limited in scope than transactional immunity, which provides immunity from prosecution "for or on account of any transaction, matter or thing, concerning which" the witness may testify. Act of Feb. 11, 1893, 27 Stat. 443 (repealed by the Organized Crime Control Act of 1970, Pub. L. No. 91-452, $\$ 245,84$ Stat. 931). Use immunity thus leaves the witness susceptible to prosecution with independently derived evidence, while transactional immunity forecloses prosecution on any matter to which the testimony relates.

The fifth amendment, however, requires only that use immunity be granted in order to compel testimony. See Kastigar v. United States, 406 U.S. 441 (1972). Thus, whenever this Comment refers to "immunity," a grant of only use immunity is contemplated.

2 See Westen, The Compulsory Process Clause, 73 MrcH. L. Rev. 71, 166-70 (1974) (arguing that the right is based on the sixth amendment); Comment, Right of the Criminal Defendant to the Compelled Testimony of Witnesses, 67 Couns. L. REv. 953 (1967) [hereinafter cited as Right of the Criminal Defendant]; Note, Separation of Powers and Defense Witness Immunity, 66 GEo. L.J. 51 (1977) [hereinafter cited as Separation of Powers]; Note, A Re-Examination of Defense Witness Immunity: A New Use for Kastigar, 10 Harv. J. Legs. 74 (1972) [hereinafter cited as A Re-Examination of Defense Witness Immunity]; Note, The Sixth Amendment Right to Have Use Immunity Granted to Defense Witnesses, 91 Hanv. L. REv. 1266 (1978) (arguing that the right is based on the sixth amendment) [hereinafter cited as The Sixth Amendment Right]; Note, "The Pub- 
have been reluctant to order immunity for a defense witness ${ }^{3}$ in the absence of prosecutorial misconduct. ${ }^{4}$ The contours of this debate have recently become more clearly defined as a result of an apparent split in reasoning between the Second and Third Circuits.

The Third Circuit held in Government of the Virgin Islands $v$. Smith ${ }^{5}$ that fundamental fairness requires a trial court to confer "a judicially fashioned immunity upon a witness whose testimony is essential to an effective defense," "at least in cases in which the government can show no "strong countervailing interest." 7 The Second Gircuit held in United States v. Turkish ${ }^{8}$ that the due process clause did not contain "a general requirement that defense witness immunity must be ordered whenever it seems fair to grant it." 9 Contrary to the Third Circuit's position, the Second Circuit ruled that "trial judges should summarily reject claims for defense witness immunity whenever the witness for whom immunity is sought is an actual or potential target of prosecution." 10

These cases pose an important question: How should a court balance the competing interests of the defendant, the witness, and

lic Has a Claim to Every Man's Evidence": The Defendant's Constitutional Right to Witness Immunity, 30 STAN. L. Rev. 1211 (1978) [hereinafter cited as The Public Has a Claim].

3 See, e.g., United States v. Praetorius, 622 F.2d 1054 (2d Cir. 1979) ("materiality of testimony sought" a major factor in determination of extraordinary circumstances); United States v. Klauber, 611 F.2d 512 (4th Cir. 1979) (no "unfair conduct by the government"), cert. denied, $100 \mathrm{~S}$. Ct. 1835 (1980); United States v. Bacheler, 611 F.2d 443 (3d Cir. 1979) (no "prosecutorial threats or intimidation"); United States v. Herman, 589 F.2d 1191, 1199-1205 (3d Cir. 1978) (no threat or intimidation), cert. denied, 441 U.S. 913 (1979); United States v. Niederberger, 580 F.2d 63,67 (3d Cir.) (no "extraordinary circumstances"), cert. denied, 439 U.S. 980 (1978); United States v. Alessio, 528 F.2d 1079 (9th Cir.) (no denial of "fair trial"), cert. denied, 426 U.S. 948 (1976). See also United States v. Gaither, 539 F.2d 753, 753-54 (D.C. Cir. 1976) (Bazelon, C.J., voting to deny rehearing en banc); United States v. Leonard, 494 F.2d 955,985 n.79 (D.C. Cir. 1974) (Bazelon, C.J., dissenting in part).

The Court of Appeals of Ohio, however, granted a defendant's request to compel the prosecutor to offer immunity to a defense witness, in a case in which there was no indication of intent to prosecute the witness for any crime in connection with the homicide in question and the testimony was vital to the defendant's alibi defense. State v. Broady, 41 Ohio App. 2d 17, 321 N.E.2d 890 (1974).

4 In a case in which the court has found prosecutorial misconduct, defense witness immunity represents a means by which the government can remedy the abuse without suffering a judgment of acquittal. See United States v. Morrison, 535 F.2d 223, 229 (3d Cir. 1976).

5615 F.2d 964 (3d Cir. 1980). 1204).

${ }^{6}$ Id. 969 (emphasis deleted) (quoting United States v. Herman, 589 F.2d at

7615 F.2d at $972,973-74$.

8623 F.2d 769 (2d Cir. 1980), petition for cert. filed, 49 U.S.L.W. 3251 (U.S. Sept. 18, 1980) (No. 80-436).

9 Id. 777.

10 Id. 778. 
the government when a defendant requests use immunity for a witness who has asserted his privilege against self-incrimination and refused to testify? The purpose of this Comment is to continue the inquiry begun by previous commentators and courts, to explore some issues in greater detail, to analyze recent developments in the case law, and to re-examine some underlying assumptions that have hindered previous analyses. After consideration of the interests of the defendant, the witness, and the government implicated by a request for defense witness immunity, the Comment evaluates existing approaches to this difficult problem and concludes that the wholesale transplantation of prosecution witness use immunity analysis to the defense witness area is a fundamental analytic error. Consequently, this Comment proposes a sequential balancing process to resolve the conflict among the relevant interests.

\section{Government of the Virgin Islands v. Smith AND United States $v$. Turkish:}

\section{Clash of Opinion Tempered by Ambivalence}

\section{A. Government of the Virgin Islands v. Smith}

In Government of the Virgin Islands v. Smith, ${ }^{11}$ the defendants sought to introduce the testimony of Ernesto Sanchez, who had previously made a statement to the police that, in effect, he and some friends, and not the defendants, had committed the alleged crime. ${ }^{12}$ Sanchez asserted his privilege against self-incrimination and refused to testify when called as a defense witness. Subsequently, defense counsel sought a grant of immunity in order to compel Sanchez to testify. The Virgin Islands Attorney General's Office, which had exclusive jurisdiction over Sanchez as a juvenile, offered to grant use immunity on the condition, as a matter of prosecutorial courtesy, that the United States Attorney consent. For unexplained reasons, the United States Attorney withheld his consent. Accordingly, the defendants were tried without Sanchez's testimony, were convicted, and sentenced.13 On appeal, the Third Circuit held that the defendants' constitutional rights had been violated and remanded the case for an evidentiary hearing to determine whether due process required that Sanchez be immunized. ${ }^{14}$

11615 F.2d 964 (3d Cir. 1980).

12 Id. 966-67. See note 179 infra.

13615 F.2d at 967.

14 Id. 966. The conviction of a fourth defendant, who would not have benefited from Sanchez's testimony, was affirmed. 
Writing for a unanimous panel, Judge Garth found that the record established a prima facie case for defense witness immunity under the Third Circuit's 1978 decision in United States $v$. Herman.15 In Herman, the court had recognized two situations in which due process might require defense witness immunity. First, in cases in which the court finds prosecutorial misconduct, defined as refusal to immunize a prospective defense witness with the "deliberate intention of distorting the judicial fact finding process," 16 the court would have the power to order acquittal unless on retrial the government granted immunity. Second, even in the absence of prosecutorial misconduct, a court may have "inherent authority to effectuate the defendant's compulsory process right by conferring a judicially fashioned immunity upon a witness whose testimony is essential to an effective defense." 17

The most significant aspect of Judge Garth's opinion in Smith was his analysis of Herman's second situation-a court's inherent authority to confer a judicially fashioned immunity even absent a finding of prosecutorial misconduct. ${ }^{18} \mathrm{He}$ based this authority on a court's inherent power to ensure that "the essential task of a criminal trial is to search for truth" ${ }^{19}$ and to prevent trials from becoming "a mere 'poker game' to be won by the most skillful tactician." 20 Thus, grants of judicially fashioned immunity were grounded in the trial court's obligation to preserve the "fundamental fairness" 21 of criminal trials.

In addition, Judge Garth enunciated for the first time procedures and standards for granting judicial immunity: "immunity must be properly sought in the district court; the defense witness must be available to testify; the proffered testimony must be clearly exculpatory; the testimony must be essential; and there must be no strong governmental interests which countervail against a grant of immunity." 22 He believed that this test was satisfied in Smith: proper application for immunity was made after the witness refused to testify; Sanchez's eyewitness testimony would exculpate the defendants; equivalent evidence was not available from an alternative source, and the United States Attorney had no interest in denying

\footnotetext{
15589 F.2d 1191 (3d Cir. 1978), cert. denied, 441 U.S. 913 (1979).

16 Id. 1204.

$17 \mathrm{Id}$.

18 See 615 F.2d at $969-74$.

19 Id. 971 .

20 Id. (quoting Williams v. Florida, 399 U.S. 78, 82 (1970)).

21 Id. 972 (citing Chambers v. Mississippi, 410 U.S. 284 (1978)).

22 Id. (footnote omitted).
} 
immunity to Sanchez as he was under the exclusive jurisdiction of the Virgin Islands juvenile authorities. ${ }^{23}$

\section{B. United States v. Turkish}

In Turkish, ${ }^{24}$ the government presented its case by calling witnesses who had been granted letter ${ }^{25}$ and statutory use ${ }^{26}$ immunity. After the government had concluded its case, Turkish and his codefendants moved that seventeen prospective defense witnesses be granted use immunity and required to testify. They argued that these witnesses could provide exculpatory testimony but would invoke their fifth amendment rights against self-incrimination if called to the stand. The district court denied the motion and the defendants appealed. ${ }^{27}$

In affirming the district court's action, Judge Newman's opinion for a divided panel ${ }^{28}$ undertook a thorough review of the issue of defense witness immunity. He found the strongest argument in favor of defense witness immunity to be based on the public's interest in the pursuit of truth. ${ }^{29}$ This interest, however, could not in-

23 Id. 974.

24623 F.2d 769 (2d Cir. 1980), petition for cert. filed, 49 U.S.L.W. 3251 (U.S. Sept. 18, 1980) (No. 80-436).

25 See note 119 infra.

26 See note 1 supra.

27623 F.2d at 771-72.

28 Judge Lombard concurred in the result but dissented from the court's opinion. Id. 779 (Lombard, J., dissenting in part).

29 Judge Newman rejected the sixth amendment as a ground for defense witness immunity. Id. 773-74. Most courts apparently agree with this conclusion. See, e.g., United States v. Herman, 589 F.2d 1191, 1199-1200 (3d Cir. 1978), cert. denied, 441 U.S. 913 (1979); United States v. Rocco, 587 F.2d 144, 146-47 (3d Cir. 1978), cert. denied, 440 U.S. 972 (1979); United States v. Trejo-Zambrano, 582 F.2d 460, 464 (9th Cir.), cert. denied, 439 U.S. 1005 (1978); United States v. Smith, 542 F.2d 711, 715 (7th Cir. 1976); United States v. Alessio, 528 F.2d 1079, 1081-82 (9th Cir.), cert. denied, 426 U.S. 948 (1976); United States v. Lacouture, 495 F.2d 1237, 1240 (5th Cir.), cert. denied, 419 U.S. 1053 (1974); In re Kilgo, 484 F.2d 1215, 1222 (4th Cir. 1973); Meyers v. Frye, 401 F.2d 18, 20-21 (7th Cir. 1968). See also United States ex rel. Tatman v. Anderson, 391 F. Supp. 68, 71-72 (D. Del. 1975); Johnson v. Johnson, 375 F. Supp. 872, 875 (W.D. Mich. 1974) (dictum); Holloway v. Wolf, 351 F. Supp. 1033, 1038 (D. Neb. 1972), rev'd on other grounds, 482 F.2d 110 (8th Cir. 1973). Numerous commentators, however, have found such a sixth amendment right. See, e.g., Westen, supra note 2, at 166-70; The Sixth Amendment Right, supra note 2.

Judge Newman also rejected the notion that the defendant's right to compel witness immunity might spring from the unfairness inherent in the advantage the government gains from its ability to immunize its own witnesses. 623 F.2d at 774. This practice, he felt, could not support a due process right to defense witness immunity because "[a] criminal prosecution, unlike a civil trial, is in no sense a symmetrical proceeding." Id. As examples of this lack of symmetry, he cited the government's power to arrest suspects and obtain search warrants, as well as the diffcult standard of proof imposed on the prosecution in criminal trials. Id. 
discriminately overbear other public concerns that cut against grants of immunity to defense witnesses. These concerns relate primarily to the burdens immunity would impose on subsequent attempts to prosecute the witness. ${ }^{30}$ Judge Newman was also concerned that a request for defense witness immunity could not be considered by a court without improperly interfering with the government's discretionary control over prosecution. ${ }^{31}$ This potential interference with prosecutorial discretion could not be altogether avoided by a judicially conferred immunity as opposed to a court order that the prosecution grant immunity. ${ }^{32}$ Judge Newman believed that, even though the judiciary has constitutional responsibilities for the fairness of a trial, a court was in "no position to weigh the comparative worth of prosecuting a defendant or his witness." 33

Judge Newman expressly rejected the approach advocated by Judge Garth ${ }^{34}$ and stated his own general procedures for disposing of future defense witness immunity requests. In his view, trial judges should summarily reject such requests if the prosecutor demonstrates that the witness has been indicted or presents to the court in camera an ex parte affidavit setting forth the circumstances supporting the prosecutor's suspicion of the witness's criminal activity. ${ }^{35}$ "No duty is [to be] imposed upon the prosecutor; he simply has an option to rely upon the witness's status as an actual or potential target of prosecution to foreclose any inquiry concerning immunity for that witness." 36 Finally, Judge Newman noted

The major weakness in Judge Newman's initially appealing argument is that courts are frequently called on to make delicate judgments accommodating the inherent lack of symmetry between defendant and prosecution and the defendant's right to a fair trial. See, e.g., United States v. Wade, 388 U.S. 218 (1967); Brady v. Maryland, 373 U.S. 83 (1963); Gideon v. Wainwright, 372 U.S. 335 (1963); Roviaro v. United States, 353 U.S. 53 (1957); Griffin v. Illinois, 351 U.S. 12 (1956); Note, Twice in Jeopardy, 75 Y YxE L.J. 262, 277-78 (1965) (The rule against double jeopardy "equalizes, in some measure, the adversary capabilities of grossly unequal litigants."). Judge Newman's argument on this point is convincing only if it is read as meaning that a showing of asymmetry in resources should not be dispositive. See notes $135-41$ infra \& accompanying text.

30623 F.2d at 775.

31 Id. 776. Specifically, defense witness immunity might (1) pose substantial obstacles for a successful, efficient prosecution of the witness; (2) force the prosecution to narrow the scope of its examination in order to avoid enlarging the scope of the witness"s immunity; and (3) "create opportunities for undermining the administration of justice by inviting cooperative perjury among law violators." Id. 775 .
32 Id. $775-77$.
33 Id. 776.
34 Id. 776-77,
35 Id. 778.
36 Id. 
that his current reasoning did not reach cases in which the prosecutor could not or would not present a claim:

If a case should arise where the witness is not an indicated defendant and the prosecutor cannot or prefers not to present any claim that the witness is a potential defendant, and if the defendant on trial demonstrates that the witness's testimony will clearly be material, exculpatory, and not cumulative, it will be time enough to decide whether in those circumstances a court has any proper role with respect to defense witness immunity. ${ }^{37}$

\section{Smith and Turkish Compared}

Smith and Turkish are not classic examples of splits between circuit courts of appeals. Although Judge Newman expressly rejects the Third Circuit's ad hoc balancing approach, he does concede that the result reached by Judge Garth in Smith was correct. ${ }^{38}$ And there is little doubt that Judge Garth would concur in at least the result of Turkish.39 Thus, the circuit split rests on Judge Newman's rather harsh rejection of the Third Circuit's test for accommodating the various interests at stake in requests for defense witness immunity.

This Comment takes the position that, despite some of the language in both the Smith and Turkish opinions, the Second and Third Circuits are, in all probability, quite close in their views on defense witness immunity. In particular, it is argued that Judge Newman's opinion, when viewed as a whole, expresses some ambivalance about the fixed position of interests that he appears to advocate. ${ }^{40}$ Further, it is suggested that it is the factual peculiarities of both Turkish and Smith that enabled each court to take the rather cavalier positions staked out with respect to balancing.

Judge Newman initially characterizes Smith as "a totally bizarre situation." 41 Later in his opinion, he explains that position in an attempt to distinguish Smith's special fact pattern from its balancing approach. For example, at one point Judge Newman states that "[Smith] was simply an instance of a prosecutor interfering, for no apparent reason, to suppress evidence that was about

37 Id. 778-79.

38 Id. 777.

39 See notes $47-49$ infra \& accompanying text. infra.

40 See notes 35 \& 36 supra \& accompanying text and text following note 44

41623 F.2d at 773. 
to become available to the accused." 42 He explained this peculiarity more completely as follows:

[Smith was] an extraordinary fact situation ... where the prosecutor opposing use immunity does not even have jurisdiction to prosecute the witness [so that] the public interest in not granting defense witness immunity appears to be non-existent. ... [I]n most situations where defense witness immunity is likely to be sought, some legitimate opposing prosecution interest will exist and constitutional fairness is not a satisfactory standard against which to assess such interests. ${ }^{43}$

Thus, it appears that, in Judge Newman's view, Smith is "totally bizarre" and "extraordinary" because it involved a situation in which the prosecutor had absolutely no legitimate interest in opposing defense witness immunity, and hence, a case in which the defendant's interests could clearly outweigh the nonexistent prosecution interest. ${ }^{44}$ In most situations, according to Judge Newman, the prosecution will have some legitimate interest in denying immunity to a defense witness. And it is the existence of any legitimate interest that Judge Newman theorizes will outweigh the defendant's interests in any case. But, contrary to some of the language in Turkish, this is not an outright rejection of balancing of prosecution and defense interests. Judge Newman simply replaces the Third Circuit's specific, ad hoc balancing approach ${ }^{45}$ with a generalized, one-time balancing of interests in which it is

42 Id. 777 .

43 Id.

44 If Judge Newman's characterization of the interests in Smith is correct, the implication is that no balancing was necessary to reach the result of Smith. This Comment, however, questions the validity of Judge Newman's interpretation of Smith as involving no legitimate prosecution interests. In drawing this conclusion, he looked to the lack of any interest on the part of the United States Attorney, who had no jurisdiction over the witness whom the defendants wanted to immunize. But it was the Virgin Islands Attorney General who refused to grant immunity to the witness, albeit on the request of the United States Attorney.

Although Smith provides no guidance on the question why the United States Attorney was consulted, it is perfectly plausible that this was done somewhat routinely as a result of prosecutorial courtesy or as a result of the unique posture of the Virgin Islands vis-a-vis the United States. See text accompanying note 110 infra. Thus, the prosecutor granting immunity in Smith, the Virgin Islands Attorney General, might well have had very real and legitimate interests-such as maintaining harmonious relations with the United States Attorney's office-in not granting immunity to the witness. If this analysis is correct, then Judge Newman's distinguishing of Smith is not very persuasive and that opinion might well represent a balancing of the defendant's interests against the legitimate interests of the Virgin Islands Attorney General.

45 See notes 142 and 152-61 infra \& accompanying text. 
decided that any legitimate prosecution interest will outweigh the defendant's interest in witness immunity. ${ }^{46}$

Even beyond this partial rationalization of the opinions, Turkish's reasoning may not be as distinct from Smith's as it first appears. This is so both because Judge Newman displays some ambivalence about his position and because his procedure for implementing his test might well require some ad hoc balancing by the trial judge.

\section{Judge Newman's Ambivalence}

Turkish shows signs of ambivalence about the position in which it fixes the balance of interests in cases in which defense witness immunity is sought. The opinion attempts to isolate Smith as sui generis and therefore providing little guidance for courts in other cases. Judge Newman neverthless attempts to demonstrate that "the circumstances of [Turkish] do not remotely approach a situation where lack of defense witness immunity could be found to deny constitutionally protected fairness." 47 This is so because the request for immunity was not timely and the proferred testimony would not have been material, exculpatory, or noncumulative ${ }^{48}$-findings that are equally fatal under the Smith test. ${ }^{49}$ Further, Judge Newman's opinion closed on an ambivalent note, recognizing yet another set of circumstances that may depart from the "general" balance of interests in these types of cases.

This ambivalence may be justified. The prosecution may not always have an interest that will outweigh the defendant's interest in a fair trial. For example, in Brady $v$. Maryland, , $^{\mathbf{1}}$ the Supreme Court ruled that the prosecution could not suppress evidence favorable to an accused, and material to either guilt or punishment, without violating the defendant's due process rights. This rule

46 See notes 145 \& 146 infra \& accompanying text. It is important to recognize that even this approach does involve balancing. In order for Judge Newman to decide that any legitimate prosecution interest can override the defendant's interests in obtaining witness immunity, he has already weighed the competing values and arrived at an accommodation. Thus, the Second Circuit is not aligned as sharply against the Third Circuit's pro-balancing approach as Judge Newman's Turkish opinion first suggests. See United States v. Praetorius, 622 F.2d 1054 (2d Cir. 1979) (a different Second Circuit panel implies acceptance of some balancing in another defense witness immunity dispute decided two weeks before Turkish).

$47623 \mathrm{~F} .2 \mathrm{~d}$ at 777 .

48 Id. 778.

19 See text accompanying note 22 supra.

50 See text accompanying note 37 supra.

61373 U.S. 83, 87 (1963). 
applies "irrespective of the good faith or bad faith of the prosecution," 52 the usual limitations imposed on prosecutorial discretion. ${ }^{53}$ Society's interest in fair trials simply overrides the prosecutor's decision to suppress evidence.

Of similar import is Roviaro $v$. United States, ${ }^{54}$ in which the Supreme Court held that the government's right to withhold the identity of an informant who helped to arrange the commission of a crime and who was present at its execution must give way to a defendant's right to a fair trial whenever the informant's testimony is material to the accused's defense. ${ }^{55}$ The government argued that the privilege of nondisclosure was necessary to further the public interest in effective law enforcement and the free flow of information..$^{56}$ The government also argued that disclosure of the informant's name might prejudice its position in future cases. ${ }^{67}$ But the Court ruled that

[t]he problem is one that calls for balancing of the public interest in protecting the flow of information against the individual's right to prepare his defense. Whether a proper balance renders nondisclosure erroneous must depend on the particular circumstances of each case, taking into consideration the crime charged, the possible defenses, the possible significance of the informer's testimony, and other relevant factors. ${ }^{58}$

The fixed balance of interests proposed by Judge Newman in Turkish seem anomalous in view of these two cases. In Brady, the prosecution's interest in withholding favorable defense evidence succumbed to the defendant's interest in a fair trial. Accepting both the Supreme Court's views in Brady and Judge Newman's stated views in Turkish yields an unacceptably illogical result. For the Turkish result that some prosecution interest in the future trial of the witness should always outweigh the defendant's interest in

$52 I d$.

53 See Separation of Powers, supra note 2, at 52, 57; Note, Prosecutor's Discretion, 103 U. PA. L. REv. 1057, 1058 (1955) [hereinafter cited as Prosecutor's Discretion]. But see Note, Discretion to Prosecute Federal Civil Rights Crimes, 74 YALE L.J. 1297, 1302 (1965) (federal courts uniformly allow United States Attorneys "absolute discretion" both in bringing and dismissing criminal prosecutions). Another ground limiting prosecutorial discretion is purposeful discrimination. See, e.g., Oyler v. Boles, 368 U.S. 448 (1962).

54353 U.S. 53 (1957).

55 Id. 60-62.

$56 I d .59$.

57 Id. 58 n.5.

58 Id. 62. 
the fairness of his own trial lies in stark contrast to the Brady result that defense interests could outweigh prosecution interests in the same trial. ${ }^{59}$

Brady may be distinguished on the ground that the prosecution interest diverged so substantially from the public interest in fairness ${ }^{60}$ that it was not the type of legitimate prosecution interest with which Turkish is concerned.61 Roviaro, on the other hand, is not vulnerable to the same distinction. There was no intimation in Roviaro that the prosecution was acting improperly. Indeed, the Court basically aligned the prosecution's position with the public interest. ${ }^{62}$ Further, the prosecution's interests in Roviaro-concern about the effect disclosure of the informant's identity would have on pending matters ${ }^{63}$-were prospective and therefore of the same type as the prosecution interests at stake in Turkish. ${ }^{64}$

\section{Judge Newman's Procedure}

If the balance of interests is to be fixed according to Judge Newman's standards, then any legitimate prosecution interest, no matter how frivolous, should foreclose inquiry into defense witness immunity, so long as the prosecution files an affidavit with the court. But it would be ironic if, in attempting to avoid interference with the prosecutor's prerogatives, the trial judge ended up abdicating his responsibility to guarantee the constitutional fairness of a criminal trial by relying on a conclusory affidavit by a prosecutor.

59 Other commentators have argued that a prosecutor's refusal to grant defense witness immunity may be tantamount to suppression of evidence under Brady. See, e.g., Separation of Powers, supra note 2, at 69; The Public Has a Claim, supra note 2, at 1224-26. The Fourth and Ninth Circuits have vaguely suggested that once the defendant establishes a need for witness immunity, refusal by the government to grant immunity may violate Brady. See United States v. Klauber, 611 F.2d 512, 515-16 (4th Cir. 1979), cert. denied, 100 S. Ct. 1835 (1980); United States v. Carman, 577 F.2d 556, 561 (9th Cir. 1978). See also United States v. Leonard, 494 F.2d 955, 985 n.79 (D.C. Cir. 1974) (Bazelon, C.J., dissenting in part); Earl v. United States, 364 F.2d 666, 666-67 (D.C. Cir. 1966) (Leventhal, J., dissenting).

60 See Brady v. Maryland, 373 U.S. at $87-88$ :

A prosecution that withholds evidence on demand of an accused which, if made available, would tend to exculpate him or reduce the penalty helps shape a trial that bears heavily on defendant. That casts the prosecutor in the role of an architect of a proceeding that does not comport with standards of justice. ...

61 See 623 F.2d at 777.

${ }^{62}$ See Rovario v. United States, 353 U.S. at 62 ("The problem is one that calls for balancing the public interest in protecting the flow of information against the individual's right to prepare his defense.").

${ }^{63}$ See note 57 supra \& accompanying text.

64 See note $3 I$ supra \& accompanying text. 
To avoid this absurd result, a trial judge would have to demand more of the affidavit, such as some showing that the prosecution's interest is "significant" as well as "legitimate." Further, even under the minimal standard of legitimacy, a trial court may end up weighing interests. For example, what legitimate interest can the prosecution have in excluding clearly exculpatory evidence from trial? ${ }^{65}$ These circumstances resemble the configuration of interests in Smith and cannot easily be dismissed as "bizarre."

Judge Newman unfortunately went much further than necessary to decide Turkish. He expressly affirmed the district judge's decision on the grounds stated in the lower court's opinion. ${ }^{66}$ Judge Newman then attempted to decide more than the case before him and the soundness of his opinion suffered as a result. Instead of distinguishing other cases as "bizarre," the opinion should have addressed these cases directly. The result of this confrontation might have been the recognition that cases involving defense witness immunity are often different and therefore more suited to ad hoc analysis than solution through the formulation and application of sweeping generalizations. Judge Newman's abhorrence of balancing can thus be discounted owing to the peculiarity of the fact situation that he was addressing.

This Comment will now turn to examining the various interests implicated by a request for defense witness immunity. The several frameworks that have been proposed for balancing these interests will then be considered and a new one proposed.

\section{The Defendant's Interests: The Due Process Basis}

The defendant's interest in defense witness immunity is easily understood: unless immunity is obtained the witness will assert his fifth amendment privilege and the defendant will be denied this testimony. The difficulty comes in translating this interest into some cognizable variable that can be weighed against the countervailing interests in the defense witness immunity calculus. Courts tend to refuse to consider the defendant's interest unless it can be tied to certain substantial constitutional rights. ${ }^{67}$ As a result, the

65 See note 86 infra \& accompanying text.

66623 F.2d at 778.

67 This is most evident in cases in which defendants base their arguments for defense witness immunity on their sixth amendment right to compulsory process. The defendant in United States v. Lenz, 616 F.2d 960 (6th Cir. 1980), attempted such an argument. The Sixth Circuit, following the lead of most other courts, see note 29 supra, held that the sixth amendment was not implicated by the government's refusal to grant the defendant's request for witness immunity. "Since the 
defense interests that courts are willing to weigh are coextensive with these particular constitutional rights of the defendant. The due process clause, in various forms, has most consistently provided the basis of these rights. ${ }^{68}$ Two particular due process bases of the defendant's right to witness immunity are examined below.

\section{A. Prosecutorial Misconduct}

The court in Government of the Virgin Islands v. Smith held that the defendant's right to compel defense witness immunity may be based on prosecutorial misconduct that rises to a violation of the defendant's due process rights. ${ }^{69}$ This rationale had its genesis in United States $v$. Morrison. ${ }^{70}$ In Morrison, the prosecution intimidated a witness who previously had asserted her willingness to testify for the defense by threatening her with prosecution if she did so. ${ }^{71}$ She responded to this threat by invoking her privilege against selfincrimination when she was called to the stand by the defense. The Third Circuit held that the prosecutor's misconduct deprived the defendant of due process and ruled that the government could avoid a judgment of acquittal only by requesting use immunity for the witness's testimony at a new trial. ${ }^{22}$

The potential breadth of this holding was subsequently limited in United States $v$. Herman. ${ }^{73}$ In Herman, the Third Circuit distinguished the explicit threat in Morrison from the implicit threat embodied in a penal statute and the availability of an indictment. ${ }^{74}$ This distinction implies that the mere refusal by a prosecutor to grant immunity to a defense witness who might incriminate himself by testifying does not constitute the type of misconduct contemplated and remedied by Morrison. ${ }^{75}$

defendant's compulsory-process right is not at stake, we need not balance it against the Government's justifications for withholding immunity." Id. 963 . Cf. United States v. Turkish, 623 F.2d 769 (2d Cir. 1980) (finding the defendant's due process interests in a fair trial an inadequate standard for balancing against the government's interests), petition for cert. filed, 49 U.S.L.W. 3251 (U.S. Sept. 18, 1980) (No. 80-436).

68 See note 29 supra.

${ }^{69}$ See text accompanying notes 15-17 supra.

70535 F.2d 223 (3d Cir. 1976).

71 Id. 225-26.

72 Id. 229.

73589 F.2d 1191 (3d Cir. 1978), cert. denied, 441 U.S. 913 (1979).

74 Id. 1200.

75 See United States v. Klauber, 611 F.2d 512 (4th Cir. 1979), cert. denied, 100 S. Ct. 1835 (1980). The distinction drawn in Herman would appear to support the treatment of Brady v. Maryland, 373 U.S. 83 (1963), by the court in Earl v. United States, 361 F.2d 531, 534 (D.C. Cir. 1966) (holding that the 


\section{B. The Right to a Fair Trial}

The goal underlying the doctrine of Brady v. Maryland is "avoidance of an unfair trial to the accused." 76 The Second, Third, and Ninth Circuits, reviewing denials of requests for defense witness immunity, have framed the central inquiry in these particular due process terms. ${ }^{77}$ Similarly, in Government of the Virgin Islands $v$. Smith, the Third Circuit considered the defendant's rights under the compulsory process and due process clauses by reference to the "fundamental fairness" 78 standard of Chambers v. Mississippi. ${ }^{79}$ Thus, courts have found it convenient to express the defendant's basic interest in defense witness immunity in terms of an inquiry into what the court deems to be fair within the context of the case.

Out of the commentary and cases, four basic fairness approaches to the defense witness immunity issue have emerged. The first approach views fairness in terms of reciprocity, conditioning consideration of the defendant's claim on the prosecution's use of immunized witnesses. ${ }^{80}$ A second approach, advanced by the Third Circuit in Smith, considers the defendant's need for immunized testimony only when no significant countervailing government interest is found to exist. ${ }^{81}$ Under a third approach, the court balances the defendant's need for particular testimony against the government's specific interest in withholding immunity from the witness. ${ }^{82}$ The fourth approach requires the court to weigh the defendant's need for specific testimony against a particular standard

government's decision to withhold immunity did not constitute suppression under Brady because the prosecution had not "affirmatively withheld a witness or concealed evidence."), which has come under attack as a result of the shift from transactional to use immunity, see, e.g., The Public Has a Claim, supra note 2, at 1214-17. This shift to use immunity, which theoretically places less of a restriction on the government's interest in subsequent prosecution of a witness, had been thought to require a re-evaluation of Brady's presumed inapplicability. Commentators espousing this position argued that the easier it became for the government to grant immunity, the closer its refusal approaches suppression within the spirit, if not the letter, of Brady.

76373 U.S. at 87.

77 United States v. Wright, 588 F.2d 31, 36 (2d Cir. 1978), cert. denied, 440 U.S. 917 ( 1979 ); United States v. Carman, 577 F.2d 556, 561 (9th Cir. 1978); United States v. Alessio, 528 F.2d 1079, 1082 (9th Cir.), cert. denied, 426 U.S. 948 (1976). See also United States v. Herman, 589 F.2d 1191, 1203 (3d Cir. 1978), cert. denied, 441 U.S. 913 (1979).

78615 F.2d 964, 970-71 (3d Cir. 1980).

79410 U.S. 284 ( 1973 ).

80 See text accompanying notes $135-41$ infra.

81 See text accompanying notes 152-68 infra.

82 See text accompanying notes 142-44 infra. 
that represents the government's general interest in maintaining prosecutorial discretion. ${ }^{83}$

To assess the equity and adequacy of these different procedures, it is necessary to consider the competing interests of the government and of the witness to see how they conflict with the defendant's due process right to a fair trial. After examining these other interests, this Comment will return to a discussion of the four fairness approaches.

\section{The Government's Interest}

Under title 18 of the United States Code ${ }^{84}$ a United States Attorney may request an immunity order when "necessary to the public interest." 85 The decision of what course of action most effectively promotes the public interest is entrusted to the United States Attorney because his responsibility for the prosecution of criminals presumably places him in the best position to weigh the reasons for and against a grant of immunity for a specific witness. In most cases, however, the prosecutor's interest in obtaining a conviction will be thwarted by a grant of immunity to a defense witness, because the immunized testimony will strengthen the defendant's case while impeding eventual prosecution of the witness. Of course, the prosecution's interest, at least in theory, is not served by the conviction of an innocent person, and to the extent that immunized testimony probative of innocence leads to an acquittal, its introduction serves both prosecution and defense interests. ${ }^{86}$ Thus, the most relevant question for the prosecution is whether and to what extent a grant of immunity will impede a subsequent prosecution of the witness.

The government's interest in withholding immunity from a particular defense witness is therefore measured by two components-the desirability and feasibility of ultimately prosecuting the witness. The desirability of prosecution will be a function of the

83 See text accompanying notes 145-51 infra.

8418 U.S.C. $\$ \S 6002-6003$ (1976).

85 Id. $\$ 6003(b)(I)$.

86 See Brady v. Maryland, 373 U.S. 83, 87 (1963):

Society wins not only when the guilty are convicted but when criminal trials are fair; our system of the administration of justice suffers when any accused is treated unfairly. An inscription on the walls of the Department of Justice states the proposition candidly for the federal domain: "The United States wins its point whenever justice is done its citizens in the courts." 
many elements that go into the prosecutor's decision whether to charge an individual with a crime and take the case to trial. ${ }^{87}$ The feasibility of prosecuting the witness will depend on the prosecutor's ability to make out a case against the witness independently of the testimony for which he is to be immunized. ${ }^{88}$

\section{A. Feasibility of Prosecution}

\section{Kastigar's Analysis of Use Immunity}

Commentators supporting a right to defense witness immunity ${ }^{89}$ have frequently relied on Justice Powell's statement in Kastigar $v$. United States" 90 that "the immunity provided by 18 U. S. C. $\S 6002$ leaves the witness and the prosecutorial authorities in substantially the same position as if the witness had claimed the Fifth Amendment privilege." 91 Using this statement describing the practical effect of a use immunity grant, the argument is that if the government does, in fact, surrender nothing when it grants use immunity to a witness, then its interest in withholding statutory immunity from any witness, including a defense witness, is negligible. The crucial question is whether this assumpton is justified. Further, even if Justice Powell's statement fairly represents the effect of granting use immunity to a prosecution witness, the question still remains whether that analysis applies with equal force to a defense witness. Most other commentators have somewhat blindly followed Justice Powell's reasoning and operated under the assumption that the government's burden in granting

87 See text accompanying note 110 infra. See also Thornburgh, Reconciling Effective Federal Prosecution and the Fifth Amendment: "Criminal Coddling," "The New Torture" or "A Rational Accommodation?", 67 J. Crm. L. 155, 158 (1976).

88 In this Comment the phrase "feasibility of prosecution" refers to the feasibility of prosecuting the witness if immunity is granted. The feasibility of prosecution once immunity is granted, however, will usually reflect the feasibility of prosecution generally, because ordinarily, when the case against a prospective defendant is strong, it will be possible to gather the evidence, certify it, grant immunity, and subsequently prosecute with the independently derived evidence. On the other hand, when the government has a weak case against a prospective defendant, the feasibility of prosecution will not be great, regardless of the immunity issue. That situation also favors a grant of immunity in most cases because when the case against the witness is weak, the desirability of ultimately prosecuting that witness tends to be less as well.

89 Westen, supra note 2, at 169; Separation of Powers, supra note 2, at 74-75; A Re-Examination of Defense Witness Immunity, supra note 2, at 84; The Sixth Amendment Right, supra note 2, at 1274. See also Government of the V.I. v. Smith, 615 F.2d 964, 973 (3d Cir. 1980).

90406 U.S. 441 (1972).

91 Id. 462 . 
use immunity is slight regardless of whether the immunized witness is to testify for the prosecution or for the defense. ${ }^{92}$

\section{The "Taint" Gases}

When a defendant claims that testimony compelled by a grant of use immunity under either 18 U. S. C. $\$ 6002$ or a similar state statute has been introduced improperly at his trial, the prosecution must show that the evidence being used against the witness is not "tainted" but was gathered independently from other sources. ${ }^{93}$ Whether the consequence for the government of granting use immunity is equivalent to allowing the witness to remain silent (and therefore whether Justice Powell's assumption is accurate) depends on how the district court interprets Kastigar v. United States. ${ }^{94}$ Kastigar places a "heavy burden" 95 on the prosecution, one that "is not limited to a negation of taint; rather, it imposes on the prosecution the affirmative duty to prove that the evidence it proposes to use is derived from a legitimate source wholly independent of the compelled testimony." 96

The taint case opinions are not entirely consistent on the standard of proof the government must satisfy to avoid a finding of taint. ${ }^{97}$ At one extreme, at least one court has indicated that in some circumstances it may be impossible for the government to overcome a prima facie case of taint. ${ }^{98}$ At a minimum, most of

92 See, e.g., Westen, supra note 2 , at 169 ("Kastigar's analysis applies with equal force to the grant of use immunity to defense witnesses.").

93 See Kastigar v. United States, 406 U.S. 441 (1972).

$94 I d$.

95 Id. 461.

96 Id. 460.

97 One district court held that the government's burden under the federal use immunity statute is measured by a preponderance of the evidence standard. United States v. Seiffert, 357 F. Supp. 801, 804 (S.D. Tex. 1973), aff'd, 501 F.2d 974, 982 (5th Cir. 1974). Another, though agreeing that the preponderance of the evidence standard was a logical choice, required the government to prove beyond a reasonable doubt that its evidence was not tainted by the witness's immunized testimony. United States v. Henderson, 406 F. Supp. 417, 423 (D. Del. 1975). The latter court reasoned that the stricter standard would encourage the government to preserve its evidence carefully before compelling testimony.

98 United States v. McDaniel, 482 F.2d 305 (8th Cir. 1973). In McDaniel, the defendant received automatic immunity under state law while testifying before a state grand jury. A federal prosecutor, unaware of the immunity, subsequently read a transcript of his testimony. The Eighth Circuit held that this perusal established a prima facie case of use of immunized testimony. United States v. McDaniel, 449 F.2d 832 (8th Cir. 1971), cert. denied, 405 U.S. 992 (1972). In an attempt at rebuttal, the government produced voluminous FBI reports to show that it had had prior knowledge of all of the information contained in 
the taint cases suggest that the government's burden of proof will be sufficiently heavy to make subsequent prosecution of immunized witnesses extremely difficult, if not impossible. ${ }^{99}$

The Third Circuit has suggested that it may sometimes be possible "to 'sterilize' the testimony of the immunized witness and so isolate it from any future testimony [sic] of the witness that it would not trench upon any of the witness' constitutional rights if he were subsequently to be prosecuted." 100 It is questionable, however, whether such "sterilization" of the testimony can adequately protect the witness's fifth amendment right, because there will always be the lingering possibility "that somewhere in the depths of [the prosecutor's] . . . investigative apparatus, often including hundreds of employees, there was . . . some prohibited use of the compelled testimony." 101

\section{Certification of Evidence}

The prohibition in Kastigar $v$. United States against any use of immunized testimony has prompted several commentators to

the state grand jury testimony. The court ruled, however, that the government failed to show that reading the testimony did not lead somehow to use of tainted evidence.

Such use could conceivably include assistance in focusing the investigation, deciding to initiate prosecution, refusing to plea-bargain, interpreting evidence, planning cross-examination, and otherwise generally planning trial strategy.

$\cdots$

-. Under these circumstances, we are of the opinion that the government is confronted with an insurmountable task in discharging the heavy burden of proof imposed by Kastigar.

482 F.2d at 311 . Cf. United States v. Dornau, 359 F. Supp. 684, 687 (S.D.N.Y. 1973) (court held that a prosecutor who reads the transcript of immunized testimony taken before a federal grand jury invalidates the indictment, even though the investigation was founded on independent evidence), rev'd on other grounds, 491 F.2d 473, 479-80 (2d Cir.), cert. denied, 419 U.S. 872 (1974). See generally Note, Standards for Exclusion in Immunity Cases after Kastigar and Zicarelli, 82 YALE L.J. I71 (1972) [hereinafter cited as Standards].

99 See Symposium: "The Granting of Witness Immunity," $67 \mathrm{~J}$. Crum. L. $129-80$ (1976) (enumerating many of the practical difficulties in prosecuting a witness who has received statutory immunity); Note, Federal Witness Immunity: Problems and Practices under 18 U.S.C. If 6002-6003, 14 AM. Crov. L. Rev. $275,282-86$ (1976) (discussing barriers to future criminal prosecutions of immunized witnesses) [hereinafter cited as Federal Witness Immunity].

100 Government of the V.I. v. Smith, 615 F.2d at 973.

101 Kastigar v. United States, 406 U.S. at 469 (Marshall, J., dissenting). Even a prosecutor acting in the best of faith risks innumerable events that could lead a reviewing court to hold his "independently derived" evidence tainted. For example, he might unwittingly rely on an informant's lead precipitated by newspaper reports of the witness's immunized testimony. See In re North America Inv. Co., 559 F.2d 464, 466 (7th Cir. 1977). See also notes 121-28 infra \& accompanying text. There is no guarantee that such mishaps always come to. light. 
suggest that the only effective means of protecting the witness's fifth amendment right is to have the prosecuting authorities gather their evidence against the witness, seal it in a dated envelope, and have the court certify it prior to compelling the witness's testimony.102 The prosecution would then be required to rely solely on the certified evidence at any subsequent trial of the witness.

In cases in which the government is capable of gathering its evidence and certifying it prior to granting a witness immunity without jeopardizing its case, use immunity may operate as envisioned by Kastigar and the government's interest in withholding immunity will be slight. Thus, the inquiry into the feasibility of subsequent prosecution of the prospective defense witness basically involves determining the degree to which the certification procedure can protect the government's capacity subsequently to prosecute the witness. This test should not be directed at the relative strength or weakness of the government's case against the witness, but rather at the nature of the investigative process required by the witness's case. ${ }^{103}$ The government could thus oppose the certification procedure only if short term, finite investigation was not suitable to the case.

In some circumstances, however, certification of evidence will not be a feasible procedure. In a case in which the defendant's request for witness immunity is unexpected, the government should be allowed a reasonable continuance to carry out its investigation of the witness. ${ }^{104}$ But a continuance will not always suffice. For example, wide-ranging criminal conspiracies may necessitate ongoing investigations from which it is impossible to extract neat packages of evidence that can be certified.

Effective prosecution of conspiracies often entails the investigative tactic known as "ladder climbing": 105 less culpable conspirators are immunized, often after being convicted themselves,

102 See The Supreme Court, 1971 Term, 86 HARv. L. Rev. I, 181 (1972); Standards, supra note 98, at 182. See also Goldberg v. United States, 472 F.2d 513, 516 n.5 (2d Cir. 1973) (citing the student works supra with approval, and urging prosecutors to adopt the certification procedure as a means of proving that evidence is independently derived).

103 See note 88 supra and text accompanying notes 104-07 infra.

104 The Third Circuit suggests this possibility as a means of mitigating the government's burden in granting immunity. Government of the V.I. v. Smith, 615 F.2d at 970 .

105 See Thornburgh, supra note 87: "Federal prosecutors, utilizing the statute, have employed the use immunity procedure to compel testimony from 'Tittle fish' to convict the 'big fish' in scores of cases involving members of organized crime and racketeering syndicates, as well as corrupt politicians, and masterminds of white collar fraud." Id. 157 (footnote omitted). 
in order to compel their testimony against more culpable coconspirators. In cases in which the "ladder climbing" tactic is frequently employed, such as corporate conspiracies and racketeering, the prosecution's evidence may consist almost entirely of testimony by those implicated in the crime. ${ }^{106}$ In these cases, and in others as well, ${ }^{107}$ the prosecution might be able to show that investigation of the witness and certification of evidence within a short time would be practically impossible. In such cases, an order of use immunity might well preclude subsequent prosecution of the witness.

\section{B. Desirability of Prosecution}

When the feasibility of prosecution is jeopardized, the inquiry logically turns next to a consideration of the desirability of prosecution, ${ }^{108}$ an issue distinct from the question of feasibility. In the latter case, a court is considering the effect its ruling would have on the government's ability to prosecute a subsequent case easily. Courts are frequently required to make decisions that have serious effects on the government's capacity to enforce the law and to seek convictions for its violation if necessary to protect some constitutional interest. ${ }^{109}$ But questioning the desirability of prosecution is an unfamiliar judicial task that threatens the normal relationship between judge and prosecutor by interfering with the latter's discretion.

Whether prosecution of a particular defendant is desirable depends on many criteria. Studies of prosecutorial decisionmaking have identified some of these elements: the nature of the offense itself; prior treatment of similar situations; the victim's status; caseload demands; anticipated public reaction; personal characteristics of the defendant; recommendations of other criminal justice

106 In Kastigar v. United States, Justice Powell observed that "many offenses are of such a character that the only persons capable of giving useful testimony are those implicated in the crime." 406 U.S. at 446.

107 Whenever the government demonstrates a legitimate need for an extension of time to carry out an investigation, an order requiring it to grant immunity to a witness may work hardship on the prosecution because certification of evidence will be ineffective as a means of preserving the case against the witness.

108 See text accompanying notes 87 \& 88 supra.

109 Criminal cases adopting the exclusionary rule provide the clearest example of this willingness to protect constitutional interests at the expense of the government's capacity to present the strongest possible case. See generally Terry v. Ohio, 392 U.S. 1 (1968); United States v. Wade, 388 U.S. 218 (1967); Miranda v. Arizona, 384 U.S. 436 (1966); Chase, The Burger Coutt, the Individual, and the Criminal Process: Directions and Misdirections, 52 N.Y.U. L. Rev. 518 (1977); Oaks, Studying the Exclusionary Rule in Search and Seizure, 37 U. Crr. L. Rev. 665 (1970). 
agencies; the prosecutor's concern for his conviction rate; the effect on law enforcement; the prosecutor's opinion on the accused's guilt, and the likelihood of conviction. ${ }^{110}$ It is the freedom and ability to assess, manipulate, order, and even disregard these variables at various stages in the criminal justice system ${ }^{111}$ that constitutes prosecutorial discretion.

Unlike the relative ease with which a trial judge could evaluate a prosecutor's claim that trial of a particular defendant would not be feasible should he be granted use immunity in exchange for his testimony in an earlier trial, it is difficult to imagine a court evaluating and then weighing the above elements against other interests that must be considered when passing on a request for defense witness immunity. ${ }^{112}$ From a practical standpoint, a court would be hobbled by the inaccessibility, if not nonexistence, of recorded information bearing on the desirability of a particular prosecution. ${ }^{113}$ A court passing on the desirability of a particular prosecution might also find itself thrust into a political, nonjudicial role. Often, a decision that prosecution is desirable in a particular case reflects a policy decision or even a political judgment ${ }^{114}$ that the case requires the immediate expenditure of public resources. On a more theoretical plane, reviewing the desirability of prosecution would directly interfere with legitimate prosecutorial discretion and pose a threat to the traditional separation of functions between

110 See Thomas \& Fitch, Prosecutorial Decision Making, 13 AM. CRM. L. REv. 507, 513-15 (1976) (summarizing the results of numerous studies of prosecutorial decisionmaking). For a discussion of elements influencing prosecutorial discretion, see J. Eisenstein \& H. Jacob, Felony Justice: An Organizational Analysis of Cruminal Courts 227-62 (1977); F. Mrller, Prosecution: The Deciston to Charge a Suspect with a Crnme (1969); Prosecutor's Discretion, supra note 53, at 1057.

111 The exercise of prosecutorial discretion has systemic effects. The impact of a decision to prosecute or not may ripple through different levels of the criminal justice system. See J. Ersenstenn \& H. JACOB, supra note 110; Kaplan, The Prosecutorial Discretion-A Comment, 60 Nw. U.L. Rev. 174, 180 (1965) ("[R]etaining a high rate of conviction was important in encouraging guilty pleas, one of the principal means of hoarding the scarce resources of prosecutorial time and effort."); Prosecutor's Discretion, supra note 53, at 1080.

112 Numerous commentators, however, though writing in other contexts, have proposed many well-considered schemes for limiting prosecutorial discretion. See, e.g., Cox, Prosecutorial Discretion: An Overview, 13 AM. Crm. L. Rev. 383, 392-93 (1976); Rabin, Agency Criminal Referrals in the Federal System: A Study of Prosecutorial Discretion, 24 STAN. L. REv. 1036, 1074-90 (1972); Sofaer, Judicial Control of Informal Discretionary Adjudication and Enforcement, 72 Colus. L. REv. 1291, 1304-73 (1972).

113 Scholars of prosecutorial decisionmaking frequently remark on the lack of recorded information in the field. See, e.g., Rabin, supra note 112, at 1042 .

114 See J. Eisenstein, Counsel for tHe Untepd States: U.S. Atrornexs IN THE PoLrmCal AND Legal System 193-205 (1978); Rabin, supta note 112, at $1045-46,1065-67$. 
judge and prosecutor. Because desirability will only be examined once it is determined that defense witness immunity would render prosecution of the witness infeasible, a court would be placed squarely in the position most feared by Judge Newman: ${ }^{115}$ choosing between the prosecution of the defendant or of the witness.

Although desirability of prosecution is a real governmental interest, unlike feasibility of prosecution or the defendant's due process rights, it is probably not an appropriate element for consideration by a court for the reasons just suggested. On the other hand, any test for determining the propriety of a defense witness immunity grant should both recognize and serve this legitimate interest.

\section{Kastigar's Fallacy and the Distinctive Problems Caused by Defense Witness Immunity}

When the prosecutor can demonstrate that a desirable prosecution of a defense witness for whom immunity is sought by a defendant would be seriously hindered by requiring the prosecution to certify its evidence, either presently or after a reasonable continuance, then the court may readily conclude that the prosecution has a legitimate interest in withholding immunity from that witness. This finding is justified because, as the taint cases demonstrate, ${ }^{116}$ granting use immunity to any witness makes prosecution of that witness more difficult and less likely to result in conviction than would be the case if the witness were permitted to stand on his claim of privilege. Once immunity has been granted, the burden of proving legitimate independent sources, even for nonevidentiary "leads," is so heavy that certification of evidence prior to the grant may be the only feasible method of protecting the government's capacity to prosecute subsequently. To rely, therefore, on Justice Powell's bald assertion that use immunity "leaves the witness and the prosecutorial authorities in substantially the same position as if the witness had claimed the Fifth Amendment privilege," 117 is to make an unwarranted assumption in many cases.

115 See text accompanying note 33 supra. Contrary to Judge Newman's view, several commentators have argued that concern for prosecutorial discretion does not pose an insuperable bar to defense witness immunity. See Separation of Powers, supra note 2, at 61-65; The Public Has a Claim, supra note 2, at 1214-21. Cf. Cox, supra note 112 , at $394-403$ (prosecutorial discretion is not necessarily inviolate under doctrine of separation of powers).

116 See notes 98 \& 99 supra.

117 Kastigar v. United States, 406 U.S. at 462. 
This reliance would be particularly unfounded in the case of a request for defense witness immunity. Interests other than the design and wording of the use immunity statute favor the government's position with respect to prosecution witnesses. These elements do not operate in a case in which a criminal defendant requests the prosecution to give his witness immunity. For example, when several persons are implicated in a crime, the prosecuting authorities derive substantial leverage from an ability to grant immunity selectively. The "public interest" requirement 118 of the federal immunity statute implies that, if the government must rely on immunized testimony to prosecute a criminal, it should immunize a person less culpable than the defendant, and, preferably, the least culpable individual capable of giving the necessary testimony. The statute's broad directive, however, allows the United States Attorney broad discretion in choosing which person to immunize. Thus, in cases in which there are several coparticipants in a crime, each capable of giving the same evidence, and each desirous of receiving immunity, the prosecutor has the latitude to grant immunity to the person willing to strike the best bargain. ${ }^{119}$

Further, because the prosecution can plan its trial strategy in advance, it is capable of investigating a potential witness carefully, and confronting him with an accumulated body of evidence. This evidence gives the prosecutor substantial leverage with which to obtain concessions from any witness to whom he decides to grant immunity. In some instances, the strength of the evidence may persuade the witness to plead guilty to certain charges before receiving immunity.

Neither the power of selection nor the advantage of time is available to the prosecuting authorities when it is a defendant who requests witness immunity. ${ }^{120}$ The basic assumption of Justice Powell's majority opinion in Kastigar v. United States is therefore text.

11818 U.S.C. $\$ 6003(\mathrm{~b})(\mathrm{I})(1976)$. See notes 84 \& 85 supra \& accompanying

119 The person may, for example, be willing to accept less than full statutory immunity. The government often grants "letter" (or informal) immunity, which can take a variety of forms. For an example of such a grant, see United States v. Quatermain, 613 F.2d 38, 45 (3d Cir. 1980) (Aldisert, J., dissenting). Further, the government "will prefer to grant a conditional immunity ... that is revocable if the witness perjures himself, rather than statutory immunity that is non-revocable and permits only subsequent perjury prosecution." Brief for the United States of America at 34, United States v. Horwitz, 622 F.2d 1101 (2d Cir. 1980).

120 The time factor will not work against the government in cases in which the prosecuting authorities have initiated or even concluded their investigation of the witness. Further, a requirement that both parties provide pretrial notice of potential witnesses would ease the time constraint, as would the availability of a reasonable continuance. 
inapplicable to defense witness immunity in two respects. First, use immunity generally may not leave the prosecution and witness in a state of equilibrium in all cases. Second, even though a prosecutor's capacity to use its immunity powers selectively and strategically may shift the balance back towards the state of equilibrium contemplated by Justice Powell's statement when the government grants immunity to a prosecution witness, those forces do not operate in cases in which it is the defendant who requests witness immunity.

\section{The Witness's INTEREST}

Before discussing the effect this analysis of the government's interest has on the choice of balancing process, it is important to consider the interest of the witness, an interest grounded in the fifth amendment right against self-incrimination. Most commentators have viewed this right as being adequately protected by a grant of statutory immunity. 121 Such confidence is justified so long as the trial court sets a sufficiently strict standard in taint cases, ${ }^{122}$ or if the government either relies solely on certified evidence at trial or follows a policy of not prosecuting immunized witnesses. ${ }^{123}$

The taint cases, however, taken as a whole, do not provide an absolutely clear picture of the extent to which a witness's fifth amendment rights are protected by a use immunity grant. Different standards of proof have been set by different courts, ${ }^{124}$ and, although rulings like the holding of United States $v$. McDaniel may have discouraged prosecutors from relying indiscriminately on their ability to prevail at taint hearings, other courts have allowed subse-

121 See note 2 supra. Other student commentators have been more skeptical. See, e.g., Comment, The Fifth Amendment and Compelled Testimony: Practical Problems in the Wake of Kastigar, 19 VIIL. L. Rev. 470 (1974); Standards, supra note 98 . These commentators have recognized that protection of the witness's fifth amendment right is dependent entirely on the way in which district courts apply Kastigar's standards in taint hearings. Further, two dissenters in Kastigar were critical of the majority's faith in the ability of use immunity to safeguard the witness's constitutional right. Kastigar v. United States, 406 U.S. 441,462 (1972) (Douglas, J., dissenting); id. 467 (Marshall, J., dissenting).

122 See note 98 supra.

123 At least one United States Attorney has asserted that the Justice Department follows an informal policy of rarely prosecuting immunized witnesses. Interview with Peter Vaira, U.S. Attorney for the E.D. of Pa., in Phila., Pa. (Jan. 31, 1980 ). See also Federal Witness Immunity, supra note 99 , at $282 \mathrm{n} .46$, citing a letter from E. Ross Buckley, Attorney-in-Charge, Freedom of Information Privacy Unit, Criminal Division, Department of Justice, stating that, although the Immunity Unit of the Department of Justice does not keep statistics on the number of witnesses who have been prosecuted for matters previously disclosed in immunized testimony, "if any such instances exist, they are rare."

124 See note 97 supra. 
quent prosecutions of immunized witnesses without certification of evidence. ${ }^{125}$

One must also consider the effect a broad right to defense witness immunity may have on future relations between prosecutors and defense witnesses. At the present, it is probable that the government has chosen not to attempt prosecution of its own immunized witnesses in many instances. It is conceivable that a sense of having immunity grants forced upon it by defendants might induce the government to pursue taint proceedings more often than it has with prosecution witnesses. ${ }^{126}$

Because it is impossible to ascertain the extent to which the "good faith of the prosecuting authorities is [actually] . . . the sole safeguard of the witness' [sic] rights," 127 it is naive to assume that defense witnesses will necessarily receive the same degree of protection that prosecution witnesses have received under the statute. With this caveat, the ensuing analysis of the competing balancing procedures to be used in evaluating requests for defense witness immunity proceeds on the assumption that a defense witness's fifth amendment rights are adequately protected by statutory immunity. ${ }^{128}$

\section{Balancing the INTEREsts}

Having examined the respective interests of defendant, prosecutor, and witness, it is possible to compare the advantages and disadvantages of the various fairness-based balancing procedures that others have proposed. ${ }^{129}$ Because the defendant's constitutional right, if any, to defense witness immunity has been most frequently based on the due process right to a fair trial ${ }^{130}$ rather than on a straightforward right to compel testimony under the compulsory

125 E.g., United States v. Catalano, 491 F.2d 268, 272 (2d Cir.) (prosecution met burden of affirmatively showing no reliance on defendant's grand jury testimony), cert. denied, 419 U.S. 825 (1974); United States v. Henderson, 406 F. Supp. 417, 423 \& n.8 (D. Del. 1975) (prosecution must prove its case beyond a reasonable doubt); United States v. Seiffert, 357 F. Supp. 801, 804 (S.D. Tex. 1973) (prosecution met burden by proving its case by a preponderance of the evidence), aff'd, 501 F.2d 974, 982 (5th Cir. 1974).

128 See note 140 infra.

127 Kastigar v. United States, 406 U.S. at 469 (Marshall, J., dissenting).

128 Of course, this assumption will require re-evaluation if defense witness immunity orders become common.

129 See text accompanying notes 80-83 supra.

${ }^{130}$ See notes 76-79 supra and accompanying text. 
process clause, ${ }^{131}$ this Comment judges each proposal by its capacity to help ensure a fair disposition of the defendant's case.

Each of the following approaches requires the same preconditions to an analysis of the conflicting interests: the defendant must have subpoenaed ${ }^{132}$ and called the witness to the stand, ${ }^{133}$ the witness must have asserted his fifth amendment privilege, ${ }^{134}$ the defendant must have requested the government to grant the witness immunity, and the government must have refused to comply with this request. With these preconditions in mind, this Comment now turns to a discussion of the four fairness-based balancing processes.

\section{A. A Right to Reciprocity}

The right of the defendant to reciprocal treatment vis-a-vis the prosecution was initially suggested by the footnote in Earl $v$. United States. ${ }^{135}$ This notion of fairness, which appears to have been adopted by the district court in United States $v$. De Palma,${ }^{136}$ conditions the defendant's right to receive witness immunity on the prosecution's use of immunized witnesses against him. Although a number of courts have relied on the Earl footnote to make the prosecutor's use of compelled testimony a prerequisite to any form of due process inquiry, ${ }^{137}$ the arbitrariness of the rule is obvious.

131 A right under the compulsory process clause presumably would not require any balancing of the government's interest. See, e.g., The Sixth Amendment Right, supra note 2.

132 See, e.g., United States v. Praetorius, 622 F.2d 1054, 1064 (2d Cir. 1979); United States v. Wright, 588 F.2d 31, 37 (2d Cir. 1978), cert. denied, 440 U.S. 917 (1979); United States v. Lacouture, 495 F.2d 1237, 1240 (5th Cir.), cert. denied, 419 U.S. 1053 (1974). In Government of the V.I. v. Smith, 615 F.2d 964, 972 (3d Cir. 1980), this prerequisite was stated as "the defense witness must be available to testify."

133 See United States v. Carman, 577 F.2d 556, 561 (9th Cir. 1978). But see United States v. Klauber, 611 F.2d 512, 514 (4th Cir. 1979) (allowing consideration, in limited circumstances, of defendant's claim despite his failure to call the witness to the stand), cert. denied, $100 \mathrm{~S}$. Ct. 1835 (1980).

134 See notes 185-89 infra \& accompanying text.

135361 F.2d 531, 534 n.I (D.C. Cir. 1966), cert. denied, 388 U.S. 921 (1967). See note I supra.

136476 F. Supp. 775, 781 (S.D.N.Y. 1979), vacated and remanded sub nom. United States v. Horwitz, 622 F.2d 1101 (2d Cir. 1980). The prosecution was given the choice of granting the requested immunity or of having the testimony of its key immunized witness excluded at the new trial. This choice of remedial options implies that the court adopted the approach of the Earl footnote.

137 The approach of the Earl footnote has been at least implicitly adopted by those courts that have disposed of cases primarily by citing Earl. See, e.g., United States v. Lang, 589 F.2d 92, 96 (2d Cir. 1978); United States v. Bautista, 509 F.2d 675, 677 (9th Cir.), cert. denied, 421 U.S. 976 (1975); United States v. Allstate Mortgage Corp., 507 F.2d 492, 494-95 (7th Cir. 1974), cert. denied, 
The Justice Department, in its appeal of De Palma, ${ }^{138}$ acknowledged the illogical basis of the approach as follows:

[I]f the defendant has any right to immunize witnesses, it is nonsensical to condition its exercise upon the fortuity that the Government has, in a particular case, exercised its ever-present power to grant immunity. If a defendant's important witnesses will not testify without immunity, due process either does, or does not, demand such immunity. ${ }^{139}$

The approach is not only potentially unfair to the defendant, but to the prosecution as well. If a defendant were able to compel testimony merely as a result of demonstrating that the prosecutor had granted immunity to some of his witnesses, the government's ability to prosecute certain crimes would be seriously restricted. For example, the reciprocity rule, if applied without consideration of the government's interests in witness immunization, would drastically curtail the practicability of the "ladder climbing" technique in prosecuting conspiracies. ${ }^{140}$ Although the prosecution's use of immunized witnesses is undeniably one element to be weighed in assessing the fairness of the trial, it should not, by itself, be the determinative consideration.

421 U.S. 999 (1975); United States v. Ramsey, 503 F.2d 524, 532-33 (7th Cir. 1974), cert. denied, 420 U.S. 932 (1975).

138 United States v. Horwitz, 622 F.2d 1101 (2d Cir. 1980).

139 Brief for the United States of America at 30, United States v. Horwitz, 622 F.2d 1101 (2d Cir. 1980).

140 Assistant United States Attorney Nathaniel H. Akerman, the prosecutor in United States v. De Palma, said that "the decision could have 'a widespread impact on Government investigations," and that "it could seriously harm the Government's 'ladder climbing' practice of giving immunity to low-level defendants to obtain their testimony against higher-level defendants." N.Y. Times, Aug. 17, 1979, at 1, col. 5. United States Attorney Robert Fiske expressed similar sentiments: "We are very concerned about the impact the decision will have on the ability of the government to successfully prosecute people at the top levels of a criminal conspiracy." Nat'l L.J., Aug. 27, 1979, at 11, col. 1.

A hypothetical may help explain how the reciprocity rule can work to hamper prosecution of conspiracies. Suppose that a prosecuting attorney has reason to believe that a politician, $P$, accepts bribes in return for government contract awards. $P$ 's "bag-man," $B$, operates a construction-supply business, through which he channels the money to $P$ that he receives as inflated payments for materials. A contractor, $C$, after some pressuring by $P$, obtained a contract to build a municipal parking lot, buying his concrete from $B$. The prosecutor, wishing to prosecute both $P$ and $B$ determines that it is in the "public interest" to compel $C$ "s testimony against $B$ by giving $C$ statutory immunity. Once $B$ is convicted, the prosecutor plans to compel $B$ 's testimony at the trial of $P$.

If the government's use of $C$ 's immunized testimony against $B$ automatically requires it to grant $P$ immunity when $B$ calls him as a defense witness, then the most culpable individual may elude prosecution. If $B$ 's testimony is essential to successful prosecution of $P$, the government will then be confronted with the choice of prosecuting either $B$ or $P$, but not both. 
Not surprisingly, therefore, commentators have unanimously rejected the reciprocity approach in favor of either one of the two following balancing processes. ${ }^{141}$

\section{B. Balancing the Government's Specific Interest}

One obvious method of avoiding the rigidity of the reciprocity rule is simply to balance the defendant's need for the testimony he is seeking to compel against the prosecution's interest in withholding immunity from that particular witness. ${ }^{142}$ The prosecutor's use of immunized witnesses would be but one of several elements to consider in evaluating the defendant's need under this approach. All the relevant facts and circumstances would be weighed by the trial judge to determine whether the defendant's need for compelled testimony outweighs the government's interest in withholding immunity from the witness in any particular case.

At least one commentator has criticized this particular balancing approach because it allows the government to withhold immunity after a rather minimum demonstration that it has an interest in prosecuting the particular witness whom the defendant wishes to immunize and that it would have difficulty doing so if immunity were granted.143 This criticism stems from the unfairness perceived in granting relief to only one of two identically situated defendants, ${ }^{144}$ merely because one requires the testimony of a witness suspected of a more serious crime, thus giving the government a greater interest in prosecuting him than the other's witness. This criticism essentially rejects the notion of including as elements in the balancing process the desirability and feasibility of prosecuting the particular witness whose testimony is sought.

\section{Balancing the Government's General Interest}

One solution to the potential disparity in treatment of identically situated defendants is to adopt a balancing procedure that looks only to the government's general interest in prosecutorial

141 See authorities cited note 2 supra.

142 This approach has been suggested by several student commentators. See Right of the Criminal Defendant, supra note 2; Separation of Powers, supra note 2; A Re-Examination of Defense Witness Immunity, supra note 2.

143 The Public Has a Claim, supra note 2, at 1220-21.

144 "Identically situated" refers to the purely hypothetical situation in which two persons are accused of the same crime, are confronted with the same adverse evidence, and share the same defense needs. 
discretion. ${ }^{145}$ This approach would involve a one-time assessment of the government's general interest in withholding immunity, rather than an ad hoc analysis of its interest in withholding immunity from each defense witness who claims his privilege against self-incrimination. The weight of the government's general interest would be incorporated into a uniform standard that all defendants would have to meet in order to receive relief. One example of this approach was Judge Newman's opinion in Turkish, which adopted an extremely high standard for defendants to meet. ${ }^{146}$ Another example of this approach is provided by one commentator ${ }^{147}$ who adopted a lower standard in suggesting that a defendant be required to show that the testimony sought to be compelled is "highly material" 148 to his defense. Once high materiality is established, the prosecution may not override the defendant's right to receive immunity by introducing evidence of its need to withhold immunity from the witness.

The problem with this approach, in addition to its deficiencies previously discussed in connection with Turkish, ${ }^{149}$ is that it will inevitably require setting a rather strict standard for gauging the defendant's need to procure witness immunity. ${ }^{150}$ Because it will involve only a one-time evaluation of the government's interest, it must account for situations in which the government's specific interest in withholding immunity is quite substantial and, consequently, establish a sufficiently rigorous standard to accommodate these situations. ${ }^{151}$ Once the standard is set, however, it will be applied to all cases, including those in which the government's specific interest in withholding immunity is relatively slight. This approach would therefore foreclose relief for those defendants unable to meet the high threshold showing of materiality, even though the prosecution, in any particular case, would have very little specific interest in withholding immunity.

The specific and general balancing approaches illustrate how inquiry into the "right to a fair trial" raises the jurisprudential

145 This approach is favored by at least one commentator. See The Public Has a Claim, supra note 2, at 1221-24.

146 See notes 24-37 supra \& accompanying text.

147 The Public Has a Claim, supra note 2, at 1221-24.

$148 \mathrm{Id}$.

149 See notes 47-64 supra \& accompanying text.

150 This result is acknowledged by the student commentator advocating the balancing of the government's general interest. The Public Has a Claim, supra note 2 , at 1235-36 n.111.

151 The alternative possibility, that courts would choose to disregard the magnitude of the government's interest when it is particularly great, is unlikely. 
question of what form of fairness we seek in criminal proceedings. The approach that balances the government's specific interest looks primarily to fairness vis-a-vis the opposition; the approach that balances the government's general interest strives to achieve fairness between identically situated defendants. These two approaches suggest another important question, one that at first glance appears as alien to any balancing inquiry as Judge Newman's approach in Turkish: Is there some point at which the defendant's need for compelled testimony is so great that no governmental concern ought to override it? This question is best considered in the context of one more approach to the defense witness immunity inquiry.

\section{The Third Circuit's Approach}

In Government of the Virgin Islands v. Smith, ${ }^{152}$ the Third Circuit reaffirmed and further developed the due process approach to defense witness immunity requests that it had begun to formulate in United States $v$. Herman. ${ }^{153}$ The court announced two testsone by which to measure prosecutorial misconduct ${ }^{154}$ of the type found in United States $v$. Morrison,,$^{155}$ and another to measure denial of what the court termed the "due process right to present an effective defense." 156

In Herman, the Third Circuit suggested the availability of a form of immunity other than statutory:

But while we think that the court has no power to order a remedial grant of statutory immunity to a defense witness absent a showing of unconstitutional abuse, a case might be made that the court has inherent authority to effectuate the defendant's compulsory process right by conferring a judicially fashioned immunity upon a witness whose testimony is essential to an effective defense. ${ }^{157}$

152615 F.2d 964 (3d Cir. 1980).

153589 F.2d 1191 (3d Cir. 1978), cert. denied, 441 U.S. 913 (1979).

154 In situations in which prosecutorial misconduct occurs, "the evidentiary showing required to justify reversal ... must be a substantial one. The defendant must be prepared to show that the government's decisions were made with the deliberate intention of distorting the judicial fact finding process." Government of the V.I. v. Smith, 615 F.2d at 968 (quoting United States v. Herman, 589 F.2d at 1204).

155535 F.2d 223 ( 3 d Cir. 1976).

156615 F.2d at 970 .

157 United States v. Herman, $589 \mathrm{~F} .2 \mathrm{~d}$ at 1204 (quoted in Government of the V.I. v. Smith, 615 F.2d at 969 (emphasis deleted)). 
The Smith court went on to set the standard that a defendant must meet in order to make a prima facie showing under this second, due process based, theory: "the defendant must make a convincing showing sufficient to satisfy the court that the testimony which will be forthcoming is both clearly exculpatory and essential to the defendant's case." ${ }^{158}$ This showing, however, is just the threshold burden that the defendant must satisfy under the Smith/ Herman test. The prosecution still has an opportunity either to rebut the defendant's showing ${ }^{159}$ or to "[establish] that the public interest would be disserved by a grant of immunity to [the] defense witness or that such a grant would entail significant costs to it." 160 If the prosecution can satisfy any of these burdens, "it would be appropriate for the immunity application to be denied." 161

There are several troubling aspects of Judge Garth's opinion in Smith. It implies, for example, that a defendant might be unable to prove that highly material evidence was sufficiently powerful to be judged "clearly exculpatory," and yet be unable to compel testimony despite the absence of any significant government interest in withholding immunity. Further, Smith suggests that even a defendant who seeks to compel undeniably and "clearly exculpatory" evidence essential to his defense may, nevertheless, be tried and convicted without that evidence being heard by the jury, if the government can demonstrate a strong countervailing interest. ${ }^{\mathbf{1 6 2}}$

It is difficult to reconcile either of these possibilities with the notion of "fundamental fairness" 163 on which the court grounded its decision. Smith's holding gives a troubling answer to the question raised at the end of the last section. Surely fairness dictates that if clearly exculpatory evidence exists, and it is within the power of the government or the court to place it before the jury, the prosecution should not be allowed to move against the defendant without that evidence being made available. The Supreme Court cases cited by the Third Circuit in support of its holding in Smith would appear to embrace at least this notion of fairness. Chambers v. Mississippi, ${ }^{164}$ Brady v. Maryland, ${ }^{165}$ Gideon v. Wain-

$158615 \mathrm{~F} .2 \mathrm{~d}$ at 970 .

159 Id. 973.

160 Id.

161 Id.

$1621 d$. 973-74.

163 Id. 972.

164410 U.S. 284 (1973).

165373 U.S. 83 (1963). 
wright, ${ }^{166}$ and Roviaro $v$. United States, ${ }^{167}$ as the Third Circuit observed, all "recognize that the essential task of a criminal trial is to search for truth." 188 This search should include the right of a criminal defendant to compel the testimony of a witness who can give clearly exculpatory evidence that is essential to his defense, irrespective of any countervailing governmental interest.

\section{A New Balancing Process}

Each of the four approaches discussed in the preceding section has its strengths and weaknesses. This Comment proposes a fifth approach, labeled "sequential balancing," that not only combines various elements of the other four approaches, but also includes a blueprint for judicial implementation. The first section below outlines the basic rules of the sequential balancing process. The following section provides a step by step description of the recommended procedures by which trial courts might implement the sequential balancing process. The four approaches discussed above will be referred to in shorthand form as the "reciprocity," 169 "specific balancing," 170 "general balancing," 171 and "Third Circuit" 172 approaches.

\section{A. Sequential Balancing}

The sequential balancing process ${ }^{173}$ proposed by this Comment is a case by case analysis requiring a threshold showing of the im-

166372 U.S. 335 (1963).

167353 U.S. 53 (1957).

168615 F.2d at 971.

169 Under the reciprocity approach, the defendant's right to obtain witness immunity is conditioned on the prosecution's use of immunized witnesses against him.

170 Under this approach, the defendant's need for compelled testimony is weighed against the government's specific interest in withholding immunity from that particular witness.

171 This approach does not involve ad hoc balancing, but instead measures the government's general interest in maintaining prosecutorial discretion with respect to immunity decisions. Once evaluated, this general interest is built into the adjudicatory process as a set standard against which all defense witness immunity claims are tested. The particular standard selected by the student commentator advocating this approach is one of "high materiality." The Public Has a Claim, supra note 2 , at 1221-24, 1235-38.

172 This is the approach formulated in United States v. Herman, 589 F.2d 1191 (3d Cir. 1978), cert. denied, 441 U.S. 913 (1979) and applied in Government of the V.I. v. Smith, 615 F.2d 964 (3d Cir. 1980).

173 This Comment's approach is labeled "sequential balancing" because it is basically a sequential process during which the parties make certain showings at certain stages not unlike hands working up a bat. This sequence may well occur 
portance and the materiality ${ }^{174}$ to the defendant's case of the testimony sought to be compelled. More specifically, once the defendant has satisfied certain procedural requirements ${ }^{175}$ and has established that the testimony he seeks to compel is not irrelevant, collateral ${ }^{176}$ to his case in chief, or cumulative ${ }^{177}$ of other evidence before the court, he then has the burden of establishing the "materiality" 178 of the testimony sought to be compelled. If the defendant demonstrates that the particular evidence is material to his case but fails to demonstrate that it is "clearly exculpatory," 179 the court must then weigh the defendant's need for the testimony against the government's interest in withholding immunity. The defendant's need is a function of both the materiality of the testimony and its importance ${ }^{180}$ to the defendant's case. Whereas materiality meas-

in other approaches to some extent, however, and even the sequential balancing process will not always follow the same pattern.

174 See notes 178 \& 180 infra.

175 See notes 132-34 supra \& accompanying text.

178 Government of the V.I. v. Smith suggests that testimony relating "only to the credibility of the government's witnesses" is too collateral. 615 F.2d at 972 . See also United States v. Praetorius, 622 F.2d 1054 (2d Cir. 1979).

177 See United States v. Alessio, 528 F.2d 1079, 1082 (9th Cir.), cert. denied, 426 U.S. 948 (1976). In Alessio, the Ninth Circuit held that the defendant was not denied a fair trial because the testimony sought was cumulative of evidence already before the jury. See also United States v. Gleason, 616 F.2d 2, 27-28 (2d Cir. 1979), cert. denied, 100 S. Ct. 1320 (1980).

178 As used in this Comment, the term "materiality" relates to the probative value of the evidence. Even though it will not necessarily affect the verdict, testimony is material if it is at all probative of facts bearing on the issue of guilt or innocence.

Evidence that is "highly material" is testimony that "could reasonably affect the outcome of the case." See The Public Has a Claim, supra note 2, at 1235.

179 "Clearly exculpatory" evidence is the most material evidence available because, if accepted as true, it would definitively establish the defendant's innocence. An example of clearly exculpatory testimony is provided by Government of the V.I. v. Smith, 615 F.2d 964 (3d Cir. 1980). Defendants Glen Smith, Elton Rieara, and Roland Georges sought to introduce the testimony of Ernesto Sanchez. Sanchez had previously made a statement to police that inculpated himself in the crime in question, and identified three others, who were nicknamed "Scotto," "Mon," and "Mouth," as perpetrators of the crime. Glen Smith, Rieara, and Georges were not known by these nicknames. Another defendant, Elvis Smith, was, however, known as "Scotto." Id. 966-67. The Third Circuit held that this testimony satisfied the "clearly exculpatory" standard. Id. 974.

180 In this Comment, the term "importance" relates not to the materiality of the testimony, but to the degree to which the evidence in question is available from only one source, the witness for whom the defendant seeks immunity. The notion of importance is also reflected in the requirement that the testimony not be cumulative of other evidence. The Third Circuit requires a showing of importance by the defendant in holding that the testimony of the witness must be "both clearly exculpatory and essential to the defendant's case." Id. 972 (emphasis added).

A standard that requires the courts to examine the importance of the evidence to the defendant's case is more flexible than one that permits the courts to look 
ures the tendency of the evidence to prove the fact that the defendant is attempting to establish, importance measures the availability of the same or equivalent evidence from another source. The government's interest ${ }^{181}$ is a function of the desirability of ultimately prosecuting the witness and of the feasibility of doing so if immunity is granted.

Thus, sequential balancing would balance the government's interest, as defined by the desirability and feasibility of prosecution of the witness, against the defendant's interest in obtaining important and material testimony. If, however, the defendant can establish that the evidence sought to be compelled is clearly exculpatory, then no balancing occurs and the witness is granted immunity. Further, it is assumed at all times, upon submission of an affidavit by the government, that prosecution of the witness is desirable.

Elements of the other standards are evident in the sequential balancing approach. For example, sequential balancing combines the flexibility of "specific balancing" with the predictability of the "general balancing" approach; it considers the defendant's case individually but also establishes absolutes at both ends of the spectrum. Beneath the threshold and beyond the ceiling, no balancing occurs. The "Third Circuit" approach's "clearly exculpatory" notion is also incorporated, albeit in modified form. Whereas the Third Circuit uses the "clearly exculpatory" requirement as a threshold to trigger the balancing process, the sequential balancing approach uses the "clearly exculpatory" test as a ceiling for balancing and grants immunity automatically once the defendant has established that the evidence is clearly exculpatory. Finally, sequential balancing reflects the "reciprocity" approach in that it considers the government's use of immunized prosecution witnesses as an element that increases the defendant's need for the desired testimony.

Concededly, this balancing process is quite technical because it attempts to articulate the delicate and complex course that judges traverse whenever they balance admitted intangibles to arrive at a decision. The following section suggests one possible procedure for implementing the sequential balancing process and for minimizing its complexity.

only at whether the evidence is cumulative of other evidence or, at the other extreme, "essential to the defendant's case." In making this judgment, a court should ensure that the other sources of evidence provide evidence that is as nearly identical to the witness's testimony as possible. Otherwise, a fair resolution of the importance inquiry may be impossible.

181 See text accompanying notes 84-120 supra. 


\section{B. The Judicial Procedure}

Most courts have required a defendant to subpoena the witness, ${ }^{182}$ to call him to the stand, ${ }^{183}$ and to elicit from him a claim of privilege ${ }^{184}$ before requesting witness immunity. This section details one proposed procedure for implementing the sequential balancing process explained in the previous section.

\section{The Witness's Claim of Privilege}

Because the witness's claim of privilege contravenes the defendant's interest in seeking the truth, the court's first task is to ensure the claim's validity ${ }^{185}$ and to confine its scope within legitimate bounds. ${ }^{186}$ To protect the witness's fifth amendment privilege, this inquiry should be made at an in camera hearing at which only the judge, witness, counsel for the witness, ${ }^{187}$ and court stenographer ${ }^{188}$ are present. If the judge finds the witness's claim of privilege to be unfounded, he must order the witness to respond to the defense attorney's questions at trial under threat of a contempt citation. ${ }^{189}$

182 See note 132 supra. This requirement serves to activate the defendant's right under the compulsory process clause of the sixth amendment.

183 See note 133 supra. This requirement is necessary to establish the defendant's need for the testimony.

184 An equivalent pretrial assurance that a witness would assert his fifth amendment privilege if called at trial would serve judicial interests in efficiency. All witnesses for both sides should be identified prior to trial, and ideally, all grants of immunity should be announced or requested at this time. Subsequent requests for witness immunity should be considered only when failure to identify the witness before trial can be adequately explained.

185 Invocation of the fifth amendment privilege must be founded on a real and appreciable danger of self-incrimination. Zicarelli v. New Jersey Investigation Comm'n, 406 U.S. 472, 478 \& n.12, 480-81 (1972); Hoffman v. United States, 341 U.S. 479,486 (1951). If and when the trial judge finds that no foundation for the privilege exists, he must order the witness to testify or risk a contempt citation.

186 Zicarelli v. New Jersey Investigation Comm'n, 406 U.S. 472 (1972), upheld a responsiveness limitation in the New Jersey immunity statute, holding that the limitation was "not a trap for the unwary; rather it is a barrier to those who would intentionally tender information not sought in an effort to frustrate and prevent criminal prosecution." Id. 477 (footnote omitted). Although the task requires sensitivity on the part of the trial judge, he must try to limit the scope of the witness's immunity to those responses to questions for which the witness claims a valid privilege, and for which the defendant has a real need.

187 Because the in camera proceeding is an inquiry into the scope of the witness's constitutional rights, he should be allowed to have counsel present.

188 The stenographer should record the entire proceeding so that a record can be sealed and kept by the court for appellate review, if necessary.

189 The nature of the contempt order is left to the trial court's discretion. At a minimum, however, a defense witness should be subject to the same contempt procedures as a prosecution witness. 


\section{The Defendant's Initial Showing}

Assuming that there is a legitimate basis for the witness's fear of self-incrimination, the court's first inquiry in the sequential balancing process is a consideration of the defendant's due process claim. ${ }^{190}$ At this stage, the government's general interest in prosecutorial discretion is represented by an initial presumption in favor of the government. The defendant must overcome this presumption by submitting an affidavit to the court describing the nature of the testimony he seeks to compel from the witness. This offer of proof should set forth in detail the questions the defense proposes to ask the witness, the expected answers to those questions, the bearing the anticipated responses would have on the defendant's case, and a demonstration that this evidence is neither cumulative 101 of other evidence to be introduced nor obtainable from another source. ${ }^{192}$

No further consideration of the defendant's request occurs unless the court finds that the testimony in question will be relevant to disposition of a noncollateral issue, not cumulative of other evidence, and not obtainable in substantially identical form from another source. These first three findings are probative of the importance of the evidence to the defendant's case. The testimony, however, must meet a further requirement: a threshold standard of materiality.

The showing necessary to overcome the presumption in favor of the government ought not be inordinately difficult, because at this stage of the balancing process the burden on the government is deemed to be mitigated by its ability to grant use immunity to the witness without great cost. Following the defendant's minimum showing that the testimony he seeks to compel will be "material either to guilt or to punishment," 193 the initial presumption in favor of the government's general interest in prosecutorial discretion will be overcome, and balancing of the two countervailing interests ensues. ${ }^{194}$

190 This inquiry may be made simultaneously with or even prior to the evaluation of the witness's fifth amendment claim of privilege.

191 See note 177 supra \& accompanying text.

192 The judge may require additional information to evaluate the defendant's need for the testimony. It may be necessary, for example, to proceed to trial to permit the judge to determine whether the testimony sought will in fact be cumulative of other evidence.

193 Brady v. Maryland, 373 U.S. 83, 87 (1963).

194 At least one court has expressed concern over the possibility of collusion between the defendant and an immunized defense witness. See United States v. Turkish, 623 F.2d 769, 775 (2d Cir. 1980), petition for cert. filed, 49 U.S.L.W. 


\section{The Government's Opportunity to Rebut}

If the testimony is found to be both material and important, the burden shifts to the government either to rebut the defendant's showing or to establish "that the public interest would be disserved by a grant of immunity to [the] defense witness or that such a grant would entail significant costs to it." ${ }^{195}$ If the government takes the former route and successfully rebuts the materiality or importance of the proposed testimony, the defendant should be allowed to bolster his argument with additional evidence. An attempt to evaluate the public interest and the cost to the government of granting immunity (the second route) will involve questions of the desirability and feasibility of prosecuting the witness if immunity is granted. The government should be permitted to establish the desirability of prosecution merely by showing that the witness has been indicted or by presenting to the court in camera an ex parte affidavit setting forth the circumstances that support the prosecutor's suspicion of the witness's criminal activity. ${ }^{196}$ The capacity of the government to gather and certify its evidence against the witness will, of course, be a key issue in the feasibility inquiry. The possible government use of immunized prosecution witnesses against the defendant will operate as an element lending additional weight to the defendant's need to compel testimony for his own benefit.

Even if the court determines that the government's specific interest in withholding immunity outweighs the defendant's initial showing of need, the court should permit the defendant to introduce at any time during the trial new evidence showing that the witness's testimony has become more essential to an effective defense

3251 (U.S. Sept. 18, 1980) (No. 80-436). A perjury prosecution may be an insufficient deterrent of potential collaboration among accomplices willing to take their chances between prosecution for the crime in question and a possible perjury charge.

Finding a solution to this problem is not an easy task. This Comment proposes the following procedure to help minimize the potentiality of collusion. Although the trial judge does not ordinarily evaluate the credibility of a witness's testimony, it may be appropriate in this situation for the judge to be alert for indications that a "deal" of immunity in exchange for some helpful, but untruthful, testimony may be afoot. In such cases, the defendant's request for witness immunity should be denied.

Depending on how this proposal is applied by individual trial judges, the results might trench too harshly on either the defendant's due process right to a fair trial or on the immunized witness's fifth amendment right not to incriminate himself. This Comment takes the position that the primary public interest is the protection of the individual's constitutional rights and that this goal far outweighs the threat that a few untruthful witnesses might be immunized. Courts should rely on the jury's ability to weigh credibility and the government's powers to prosecute perjurers to guard against duplicitous testimony.

195 Government of the V.I. v. Smith, 615 F.2d at 973.

196 Cf. United States v. Turkish, 623 F. 2d at 771-78 (2d Cir. 1980) (setting forth a similar procedure dispositive of the entire issue). 
than was initially indicated. ${ }^{197}$ If, as a result of the introduction of new evidence, the court finds the defendant's need to be weightier than the government's interest, the judge should inform the government of its remedial options. ${ }^{198}$

\section{Beyond the Balancing Point}

The premise that justifies balancing the government's general interest is that there exists a point beyond which the defendant's need for particular testimony is so great that no governmental interest justifies prosecuting the defendant without it. In the "general balancing" approach that point is reached when the court finds the proposed testimony to be "highly material" to the defendant's case. The sequential balancing approach places that point slightly higher on the materiality scale, allowing for a more flexible weighing process. Thus, balancing of the competing interests occurs over a broader range of possible variations.

No balancing should occur, however, beyond the point at which the testimony is found to be "clearly exculpatory." To prosecute the defendant while denying him such testimony at trial violates any notion of fundamental fairness. It could never be in the public's interest to deny a defendant access to clearly exculpatory evidence. As the Supreme Court recognized in Brady v. Maryland, the government's interest is served "whenever justice is done its citizens in the courts." 199 Unless comparable evidence is available from another source, a finding by the court at any time during the proceedings that the testimony at issue will be clearly exculpatory requires the court to inform the government of its remedial choices. ${ }^{200}$

\section{The Government's Remedial Choices}

Once the court has established either that the defendant's interests outweigh the government's or both that no other source of identical evidence is available ${ }^{201}$ and that the testimony sought is

197 This opportunity should remain available because the full significance of the witness's testimony to the defendant's case may not be apparent until well into the trial.

198 See notes 201-10 infra \& accompanying text.

199373 U.S. at 87.

200 See notes 201-10 infra \& accompanying text.

201 Such an alternative source of evidence may be admission of the grand jury testimony or some other out of court statement by the witness under an exception to the hearsay rules. See, e.g., United States v. Klauber, 61I F.2d 512, 517 (4th Cir. 1979) (arguing that the witness's grand jury testimony might have been admissible as a less restrictive alternative to an immunity grant under the "criteria of the general hearsay exception found in Rules 803(24) and $804(\mathrm{~b})(5)$ of the Federal Rules of Evidence."), cert. denied, 100 S. Ct. 1835 (1980). But see 
clearly exculpatory, the government must be informed of its remedial options. Traditionally, these options have been limited to a choice between conferring statutory immunity on the defense witness or dropping charges against the defendant.202 The district court in United States $v$. De Palma ${ }^{203}$ granted a third possible remedy-a motion for a new trial at which the testimony of the government's immunized witness would be suppressed. This approach recognizes the reciprocity theory advanced in the footnote in Earl $v$. United States, ${ }^{204}$ in which the defendant's right to relief is conditioned on the prosecution's use of immunized testimony against him. This remedy may represent a fair accommodation in situations in which the government's case is based heavily upon immunized testimony, but it will not always serve to ensure the defendant's right to a fair trial because it ignores cases in which, regardless of a prosecutor's strategy, clearly exculpatory testimony cannot be obtained without a grant of defense witness immunity.

In United States $v$. Herman ${ }^{205}$ and in Government of the Virgin Islands $v$. Smith, ${ }^{206}$ the Third Circuit has placed a substantial emphasis on the difference between ordering the government to grant a witness statutory immunity and fashioning a form of judicial immunity similar to that approved in Simmons $v$. United States. ${ }^{207}$ That circuit apparently based this distinction on the belief that it did not have authority to order the executive branch to remedy the situation "absent a showing of unconstitutional abuse." 208 In practice, the two forms of immunity may have identical effects, so long as the same standards are imposed at later taint

United States v. DePalma, 476 F. Supp. 775,776 n.4 (S.D.N.Y. 1979) (the "complicated interplay of rights, those of the Government, of the defendant, Horwitz, and the witnesses who now claim their Fifth Amendment privilege, do not permit a clear enunciation of the interests of justice sufficient to involve the exception of Rule $804(\mathrm{~b})(5) . ")$, vacated and remanded sub nom. United States v. Horwitz, 622 F.2d 1101 (2d Cir. 1980).

202 Whether the government's case against the defendant is dismissed with prejudice may depend on the circumstances under which the immunity request arises. For example, when the prospective witness is alleged to have an exculpating alibi, the government may be able to drop its charges against the defendant pending further investigation of the witness without forever losing the ability to reopen its case against the defendant.

203476 F. Supp. 775 (S.D.N.Y. 1979), vacated and remanded sub nom. United States v. Horwitz, 622 F.2d 1101 (2d Cir. 1980).

204 See note I supra.

205589 F.2d 1191 (3d Cir. 1978), cert. denied, 441 U.S. 913 (1979).

200615 F.2d 964 (3d Cir. 1980).

207390 U.S. 377,394 (1968).

208 Government of the V.I. v. Smith, 615 F.2d at 969 (quoting United States v. Herman, 589 F.2d at 1204). 
hearings. The government will retain the same capacity to drop its case against the defendant if it prefers to prosecute the witness without having to certify its evidence or to substantiate independent sources of evidence subsequently. The government will also suffer the same burdens as if it was ordered to grant immunity. As Judge Newman recognized in Turkish, ${ }^{209}$ judicially fashioned immunity cannot be granted without an assessment of its implication on the executive branch. In his view, however, such an assessment could not be undertaken by a court without undermining the judicial deference normally shown to prosecutorial discretion. ${ }^{210}$ By limiting a court's inquiry to the feasibility of prosecution, however, the sequential balancing approach can implement a judicially fashioned immunity that recognizes government interests, while at the same time avoiding the interference with prosecutorial discretion that would occur were the court to review the desirability of prosecution.

\section{Conclusion}

The courts have recognized that a criminal defendant's right to receive a fair trial demands that some form of relief be available to a defendant whose witness refuses to testify at trial on fifth amendment grounds. The government has a legitimate competing interest when it cannot preserve its case by certifying evidence against a witness prior to immunization. In these instances fairness requires some form of balancing approach. Each of the four basic approaches that have been proposed by courts and commentators has its strengths and weaknesses. Each may produce a fair result in certain cases, but none of them assures a fair process of adjudication in all instances. A process that is fair under all circumstances may be unattainable. This Comment, by combining the strengths of each approach, has attempted to create a process that is sufficiently flexible to render a fair result in a variety of cases. It has formulated a procedure that may appear overly technical. Such an impression, however, may be the inevitable consequence of the Comment's goal, which has been to articulate the specific questions and decisions, as well as the applicable criteria, at each step of the proceeding. As should be apparent at this point, the determination whether to grant defense witness immunity in any case is agonizingly complicated and not susceptible of simple or automatic resolution.

209 United States v. Turkish, 623 F.2d 769, 776 (2d Cir. 1980), petition for cert. filed, 49 U.S.L.W. 3251 (U.S. Sept. 18, 1980) (No. 80-436).

210 Id. 